\title{
Study of Probable Toxic Effects of Bisphenol A \& the Protective Role of Vitamin $E$ on Testes and Prostate of Adult Male Albino Rats
}

\author{
Bothina H.F. Omran, Eman A.A. Abdallah ${ }^{1}$ and Mai M. Abdelwahab ${ }^{2}$ \\ ${ }^{1}$ Departments of Forensic Medicine and Clinical Toxicology. \\ 2 Departments of Pathology. \\ Faculty of Medicine, Zagazig University, Alsharqia, Egypt.
}

\begin{abstract}
Objective: Bisphenol A (BPA) is used in industries in wide range. It is usually detected in the environment and has oestrogenic effects which are usually harmful to the reproductive system. Exposure to some oestrogenic compounds alters the growth and development of the reproductive organs that may lead to infertility or cancer. Aim: The aim of this work is to detect the Bisphenol A effects on testes and prostate of adult male albino rats and assess the protective role of vitamin E. Material and methods: 30 adult male albino rats were used in this study. They were divided into 4 groups: Group I (control group) (12 rats): which subdivided into 2 equal subgroups: Subgroup (A) (negative control group): 6 rats received only regular diet and water to determine the basic values of performed tests for 8 weeks. Subgroup (B) (vehicle control group): 6 rats received $1 \mathrm{ml}$ of corn oil (the vehicle of BPA and vitamin E) by oral gavage once daily for 8 weeks. Group II (vitamin E treated group) (6 rats): Each rat gavaged orally with $200 \mathrm{mg} / \mathrm{kg}$ body weight vitamin E once daily for 8 weeks. Group III (Bisphenol A treated group) (6 rats): Each rat gavaged orally with $325 \mathrm{mg} / \mathrm{kg}$ body weight BPA (1/10 LD 50) in 1ml of corn oil as a vehicle once daily for 8 weeks. Group IV (Bisphenol A and vitamin E treated group) (6 rats): Each rat gavaged orally with (200 mg/kg body weight vitamin $\mathrm{E}$ then $325 \mathrm{mg} / \mathrm{kg}$ body weight Bisphenol A) once daily for 8 weeks. Serum levels of testosterone were estimated. Testes and prostate histopathological and immunohistochemical examination were performed. The results: The results after being statistically analyzed and tabulated revealed that oral BPA adminstration induced a significant decrease in serum total testosterone levels. It also induced histopathological alterations in testes and prostate with increased Caspase3 immunoreactivity. Conclusion: It was concluded that oral BPA adminstration induced destructive effects in the testes and prostate, and vitamin E administration during exposure to BPA offers protection against its damaging effect. Recommendations: The use of BPA must be decreased and avoid the improper usage of plastic containers in order to decrease the health hazards resulting from BPA exposure. Administration of vitamin E may ameliorate the adverse effects of BPA on the function of reproductive system.
\end{abstract}

Keywords Bisphenol A, Vitamin E, Testis, Prostate, Spermatogenesis.

\section{Introduction}

Bisphenol A (BPA) is considered one of the most B common industrial manufactured chemicals all over the world (Bosch et al., 2016). Its molecule is small (228 Da), its color is white and at room temperature exists as a solid particles and has an odor of phenol (Ahmed et al., 2015). It is commonly used in manufacture of plastic and epoxy resin which is used a lot by consumers and act as a monomer in the steps of polymerization reaction (Bosch et al., 2016). BPA molecules remain in the environment for 2.5- 4 days 
which considered a short half-life. Its psudopersistant character comes from the constant release from plastic containers have BPA in its composition (Bosnjak et al., 2014).

Exposure to BPA resulting from consuming food in containers which have BPA in their component, for example baby bottles, table ware and cans for food preservation which are coated with epoxy resins producing a direct absorption as an exposure pathway (Heindel et al., 2015). Newly, it has been revealed that BPA can be transmitted directly through the skin from some types of thermal printing paper, for example: cashier's receipts (Helal et al., 2013). Subsequently, BPA is a universal synthetic material in the environment found nearly in all examined serum samples taken from people in developed countries; it can be found in human serum, urine and placental tissue samples, amniotic fluid, and blood taken from umbilical cord (Bosch et al., 2016).

Bisphenol A has the same size and shape of estradiol molecule. It is usually disturb the endocrine function of the body. It acts on estrogen receptors. It is less active than human estrogen but very small amount of BPA (about 2-3 ppb) can induce hormonal activity inside the cytoplasm of cells (Bosnjak et al., 2014).

Furthermore, it was found that BPA acts as an antagonist for the androgenic receptors (AR) which considered the main regulatory component of androgen cell signaling. Androgen receptors are very important for the function of male reproductive system and its development, counting one of the most important processes which is spermatogenesis (Preethi et al., 2014). Moreover, BPA decreases the activity of aromatase enzyme via two steroidogenic enzymes, (Testosterone and E2 synthesis). Aromatase usually appear in the brain, Leydig cells and adipose tissue and is important in the synthesis of steroid hormones. It can catalyze the irreversible alteration of androgens into estrogens (Helal et al., 2013).

Reproductive function eventually determined by the suitable organization of the hypothalamicpituitary-gonadal (HPG) axis, proper harmony of the neurological and endocrinal systems including the hypothalamus; the pituitary gland, found underneath the brain; and the gonads (Heindel et al., 2014).

An earlier study showed that mitochondrial enzymes in the testis diminished in mice after BPA exposure (Anjum et al., 2011). BPA has been described to encourage the alteration of xanthine dehydrogenase into xanthine oxidase in the rat liver cells thereby increasing the reactive oxygen species (ROS) (Sakuma et al., 2010).ROS generation and oxidative DNA may be responsible for the detrimental side effects of BPA on the human body (Gurmeet et al., 2014).

Multiple reports have shown toxicity of testis after exposure to BPA presented by clinical implications even with exposure to low doses. It shows decrease in the function and production of sperms in the male mice offspring (Mourad and Khadrawy, 2012).

Prostatic glands need androgens for their development, maturation and proper function. Androgens have a role in the formation of benign and malignant prostatic tumors (Hussein, 2015). Also, estrogen role in prostate pathogenesis can be mediated through several mechanisms, including genotoxicity, hyperprolactinemia, chronic inflammation and prostatic estrogen receptor-mediated procedures (Ho and Habib, 2011). Therefore, early life exposure to BPA, expressively affect numerous characteristics of prostate growth. Yet, slight data available on the sound effects of adult contact to BPA on the prostate. Chitra et al. (2003) revealed that BPA exposure can cause increasing of the ventral prostate of adult rat even at low dose.

Apoptosis is a common physiological and pathological condition which is identified as programmed cell death process. It is involved in spermatogenesis in which apoptosis of germ cell is important to remove abnormal sperm cell to provide convient quality and quantity of sperms ( $\mathrm{Li}$ et al., 2009). A lot of factors are responsible for apoptosis of germ cells such as hormone deprivation, exposure to heat and radiation and toxicants (Helal et al., 2015). Occurrence of excess or unusual apoptosis of germ cells is acommon cause for oligozoospermia and azoospermia. Fas/Fas-Ligand, bcl-2 family, Tumor protein p53, hsp, c-myc, and CASP family are involved in the regulation of germ cell apoptosis (Elobeid and Hassan, 2015).

Caspase is one of cysteine proteases within cells. Caspase activation is very important in apoptosis process. Caspase-3, originate from apoptosis and is accountable for the cleavage of the main cellular proteins, leading to typical morphological variations detected in cells suffering from apoptosis. The present study spots the light on the apoptosis as a factor sharing in BPA toxicity of male reproductive system ( $\mathrm{Li}$ et al., 2009).

One of the essential fat-soluble vitamins is vitamin E which is primarily found in some plants. Vegetable oils are very rich in vitamin E (especially wheat germ, soybean and corn oils), margarine, nuts, seed, cereal grains and vegetables (Srivastava and Gupta, 2016). Vitamin E includes eight naturally occurring isomers in two classes designated as tocopherols and tocotrienols, but with different biologic activities. The highest biologic activity exists in the $\alpha$ tocopherol and it is the most available compound of vitamin $\mathrm{E}$ in food and commercially available vitamin $\mathrm{E}$ supplements. Vitamin $\mathrm{E}$ is an antioxidant which can hunt free radicals, which can start or propagate the oxidation of lipid chain by direct or indirect way (Pekiner, 2003).

The effects and mechanism of BPA toxicity on reproductive system still remain unclear. Majority of the population especially in the developing countries may not be aware of the harmful effects of BPA on the human body (Srivastava and Gupta, 2016). Hence, this study aimed to observe the effects of BPA on testes and prostate of adult male albino rats and explore the protective role of vitamin $\mathrm{E}$.

\section{Materials and Methods}

\section{Chemicals and preparation}

1) Bisphenol A (BPA):

It is beige odourless crystalline powder dissolved in corn oil. Its CAS No is 80-05-7. It was manufactured by 
Sigma-Aldrich Chemical Company, Germany and purchased from Sigma -Egypt.

2) Vitamine E:

It is oily odorless substance, soluble in corn oil. It was obtained from Safe Pharma for Pharco Pharmaceuticals, Alexandria, Egypt.

3) Corn Oil:

It is used as vehicle for BPA and vitamin E. It was obtained from Sekem, Cairo.

\section{Experimental Animals and Design}

The study was carried out on 30 adult male albino rats with average weight of (150-200) gm; with average age of 50-60 days; they were obtained from the Animal House in Faculty of Medicine Zagazig University. They were kept under hygienic conditions and fed on a balanced diet and water ad-libitum.

Environmental factors:

The study was conducted at the Animal House of Faculty of Medicine Zagazig University.

It was performed in accordance with the guidance of ethical committee for research on laboratory animals

\section{Methods:}

(1) Experimental design:

The rats were divided into 4 groups as follow: Group I (control group) (12 rats): which subdivided into 2 equal subgroups: Subgroup (A) (negative control group): 6 rats received only regular diet and water to determine the basic values of performed tests for 8 weeks. Subgroup (B) (vehicle control group): 6 rats received $1 \mathrm{ml}$ of corn oil (the vehicle of BPA and vitamin E) by oral gavage once daily for 8 weeks. Group II (vitamin E treated group) (6 rats): Each rat gavaged orally with $200 \mathrm{mg} / \mathrm{kg}$ body weight vitamin E once daily for 8 weeks (Ogutcu et al., 2006). Group III (Bisphenol A treated group) (6 rats): Each rat gavaged orally with $325 \mathrm{mg} / \mathrm{kg}$ body weight BPA (1/10 LD 50) in $1 \mathrm{ml}$ of corn oil as a vehicle once daily for 8 weeks. The LD50 of BPA for rats is $3250 \mathrm{mg} / \mathrm{kg}$ body weight after oral administration (Chapin et al, 2008). Group IV (Bisphenol A and vitamin E treated group) (6 rats): Each rat gavaged orally with $(200 \mathrm{mg} / \mathrm{kg}$ body weight vitamin E then $325 \mathrm{mg} / \mathrm{kg}$ body weight Bisphenol A) once daily for 8 weeks.

(2) Sampling:

After 8 weeks (24 hours from the last dose) rats of all groups were subjected to:

\section{Blood sample:}

Venous blood samples were obtained from animals by means of capillary glass tubes from the retro-orbital plexus under light ether anesthesia as described by (Nemzeket al, 2001). Three ml of blood were collected from each rat in clean centrifuge tube and incubated at $37^{\circ} \mathrm{C}$ until blood clotted and then centrifuged to separate the serum.

The blood samples were used for estimating the total testosterone levels.

\section{Testes and prostate samples:}

The rats were anesthetized by ether then sacrificed. The testes and prostate were dissected and examined as following:

For the microscopic histopathological examination, testes specimens were fixed in Bouin's solution and prostate specimens were fixed in $10 \%$ formalin.

(3) Total testosterone level:

Total testosterone hormone in serum samples were measured by enzyme-linked immunosorbent assay (ELISA) according to the method of (Griffen and Wilson, 1992). Kit used was The BioVendor rat/mouse Testosterone ELISA Kit, measured by (Spectra) ELISA reader.

(4) Histopathological studies:

Macroscopic features of testes and prostate were recorded. Then samples of the testes were fixed in Bouin's solution and samples of the prostate in $10 \%$ formalin. Next to fixation, testes and prostate were fixed in paraffin blocks as usual and managed for the preparation of $3-5 \mu$ thick sections. Sections were deparaffinized, rehydrated, and exposed to hematoxylin and eosin stain to assess variations in the morphology and examined by light microscope (Bancroft and Stevens, 1997).

(5) Immunohistochemistry studies:

The immunohistochemical staining procedure for caspase-3 was performed by streptavidin-biotin immunoperoxidase method (Dako-Cytomation, Glostrup, Denmark). Tissue sections were cut at 3-5 $\mu \mathrm{m}$ thickness from theblocks on positively charged slides then xylene was used to remove the paraffine and rehydrated by graded alcohol. After this, sections were heated in buffered citrate ( $\mathrm{pH}$ 6.0) for 20 minutes, and then washed in PBS (pH 7.3). Endogenous peroxidase activity was blocked using 6\% $\mathrm{H} 2 \mathrm{O} 2$ in methanol. The immunohistochemical staining for caspase-3 was performed with a ready-to-use rabbit polyclonal antibody (Lab Vision, New York, USA; cat. RB-1197). The slides were incubated for $2 \mathrm{~h}$ with the primary antibody at room temperature, and washed by using PBS. After rinsing in PBS, slides were immersed with a biotin-conjugated secondary antibody (Lab vision Corporation, Fermont, USA). DAB and Mayer's hematoxylin were used as a chromogen and as a counter stain respectively. Then, the slides were washed with distilled water and PBS. Positive and negative controls were stained with the same setting of the studied cases. The negative controls were done using the same tissue with the omission of the primary antibody. Staining was noticed as absent, weak, moderate or strong, whereas positivity was expressed as the percentage of immunoreactive cells over the total number of cells (Papadopoulos et al., 2013).

(6) Statistical analysis

Data collected throughout laboratory investigations and outcome measures coded, entered and analyzed using Microsoft Excel software. Data were then imported into Statistical Package for the Social Sciences (SPSS version 20.0) (Statistical Package for the Social Sciences) software for analysis. According to the type of data, the following tests were used to test differences for significance; Differences between multiple means (quantitative variables) were compared by ANOVA test, Followed by LSD. P value was set at $<0.05$ for significant results, $<0.01$ for high significant result and $<0.001$ for very high significant result. 


\section{Results}

\section{Total testosterone results:}

As comparing the hormonal level assay results of total testosterone $(\mathrm{ng} / \mathrm{ml})$ of the negative control group

I (A) and the vehicle control group I (B) were within normal values. There was no statistically significant difference between them all over the periods of the study $(p>0.05)$. So the results of the negative control group were used for comparison with those of treated groups.

There was a non-significant difference $(\mathrm{p}>0.05)$ in total testosterone level mean values between vitamin E treated group II and control group I. However, the serum testosterone level mean values of Bisphenol A treated group III showed a significant decrease $(p<0.05)$ compared to both control group I and vitamin E treated group II. Also there was a significant decrease $(p<0.05)$ in total testosterone level mean values of Bisphenol A \& vitamin E treated group IV compared with both control group I and vitamin $\mathrm{E}$ treated group II. At the same time there was a significant increase $(\mathrm{p}<0.05)$ in total testosterone level mean values of Bisphenol A \& vitamin E treated group IV compared with those of Bisphenol A treated group III (Tables 1, 2).

2. Histopathological results (Light microscopic examination of H\&E stained sections):

Testes

Group I, II:

The microscopic examination of H\&E stained sections of the testes of the control rats showed thick fibrous tissue capsule with underneath blood vessels. Seminiferous tubules showed normal structure, they were lined by spermatogonia, followed by successive layers of germinal epithelium at various stages of spermatogenesis with normal supporting cells of Sertoli (Fig 1a).

Group III (Bisphenol A treated group):

The testes showed disorganization, marked sloughing of the germinal epithelium and damage of some seminiferous tubules wall .Also, there is accumulation of pinkish edematous fluid between them. There are few number of spermatids inside the lumen of seminiferous tubules, some of the tubules show no mature spermatozoa in their lumen (Fig 1b,c).

Group IV (Bisphenol A and vitamin E treated group):

The testes showed irregular placement of germinal epithelium on the basement membrane and disruption. The number of spermatogonia is reduced with some degree of germinal epithelia sloughing (Fig1d).

Prostate:

Group I, II:

The prostate of control rats showed normal prostatic gland and lobules containing mucous secretory units (acini) (Fig 2 a).

Group III (Bisphenol A treated group):

The prostate showed marked degree of hyperplasia in most of acini, the hyperplasia obstructed the lumen of some prostatic alveoli .Other alveoli showed the presence of papillary projections in their lumen (Fig 2b,c).

Group IV (Bisphenol A and vitamin E treated group):

The prostate demonstrated degeneration of epithelial cell and some epithelia shows sloughing, slight hyperplasia of lining epithelia and few papillary projections toward alveolar lumen (Fig 2d)

3. Immunohistochemical results (Light microscopic detection of Caspase-3):

In the control groups (I, II), almost no specific caspase-3immunoreactivity was detected (Fig. 3a, 4a). In group III moderate to strong labeled active caspase3-positive cells were seen. In testes, the active caspase3immunostaining mainly was observed in Leydig cells and primary spermatocytes(Fig 3b,c), while in prostate it involved cells lining the alveoli (Fig 4 b, c).However, some moderately staining was found in group IV (Fig 3d, 4d).

Table (1): Statistical comparison between mean values of total testosterone (ng/ml) in group I (A) (-ve control), group II (Vitamin E), group III (Bisphenol A) and group IV(Bisphenol A \& vitamin E) after 8 weeks of treatment using ANOVA (analysis of variance) test:

\begin{tabular}{|c|c|c|c|c|c|c|}
\hline $\begin{array}{l}\text { Group }(n=6) \\
\text { Variable }\end{array}$ & $\begin{array}{l}\text { Group I (A) } \\
\text { (-ve control) }\end{array}$ & $\begin{array}{c}\text { Group II } \\
\text { (Vitamin E) }\end{array}$ & $\begin{array}{c}\text { Group III } \\
\text { (Bisphenol A) }\end{array}$ & $\begin{array}{c}\text { Group IV } \\
\text { (Bisphenol A } \\
\text { \& vitamin E) }\end{array}$ & $\mathbf{F}$ & $\mathbf{p}$ \\
\hline $\begin{array}{l}\text { Testosterone: } \\
\text { (ng/ml) } \\
\text { Mean } \pm S D\end{array}$ & $4.928 \pm 0.187$ & $4.987 \pm 0.144$ & $1.718 \pm 0.487$ & $2.767 \pm 0.212$ & 187.55 & $<0.001 * *$ \\
\hline
\end{tabular}

SD: Standard Deviation. **: highly significant (<0.001). NS: Non significant (>0.05). n: Number of rats in each group 
Table (2): Statistical comparison of the mean values of total testosterone (ng/ml) in group I (A)(-ve control), group II (Vitamin E), group III (Bisphenol A) and group VI (Bisphenol A \& vitamin E) after 8 weeks of treatment using least significant difference test (LSD) test:

\begin{tabular}{|c|c|c|c|}
\hline Group (n=6) & $\begin{array}{c}\text { Group II } \\
\text { (Vitamin E ) }\end{array}$ & $\begin{array}{c}\text { Group III } \\
\text { (Bisphenol A ) }\end{array}$ & $\begin{array}{c}\text { Group IV } \\
\text { (Bisphenol A \& vitamin E ) }\end{array}$ \\
\hline $\begin{array}{c}\text { Group I(A) } \\
\text { (-ve control) }\end{array}$ & $\begin{array}{c}\mathbf{0 . 0 5} \\
\text { NS }\end{array}$ & $<0.01^{*}$ & $<0.01^{*}$ \\
\hline $\begin{array}{c}\text { Group II } \\
\text { Gitamin E ) }\end{array}$ & & $<0.01^{*}$ & $<0.01^{*}$ \\
\hline Bisphenol III $)$ & & & $<0.01^{*}$ \\
\hline
\end{tabular}

*Significant (<0.01),NS: Non significant (>0.05),n: Number of rats in each group

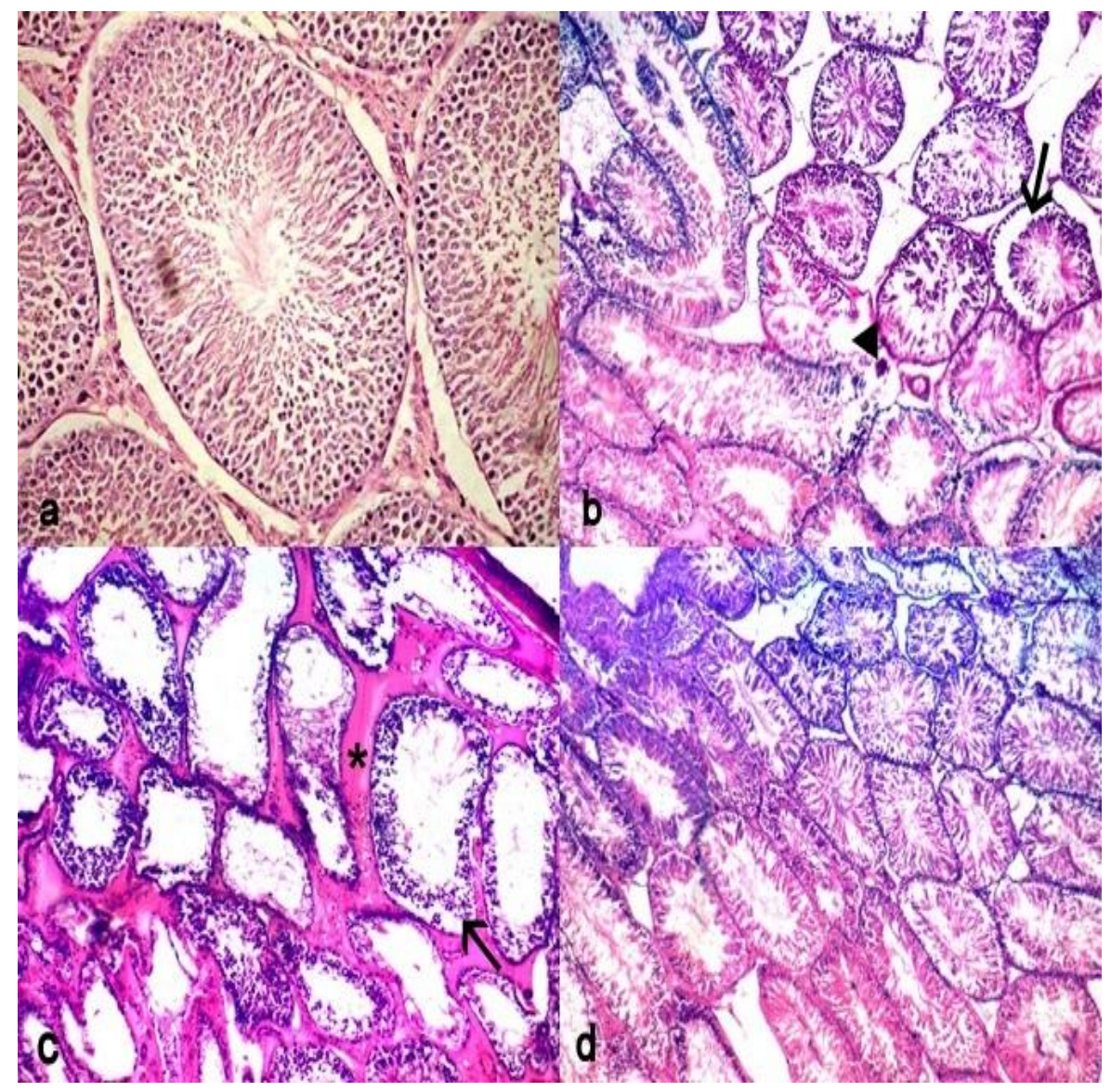

Figure (1): Histopathological features of rat testes: a) Section from control group showing normal structures of seminiferous tubules and spermatocytes (H\&Ex400). b, c) Section from group III (Bisphenol A treated group) showing sever sloughing of the germinal epithelium (arrow), destruction of the wall of some seminiferous tubules(arrow head) and accumulation of pinkish edematous fluid between them(star). There is little number of spermatids in the lumen of seminiferous tubules, some of the tubules show no mature spermatozoa in their lumen (H\&Ex200). d) Section from Group IV (Bisphenol A and vitamin E treated group) showing disruption of germinal epithelium with mild reduction of spermatogonia number and mild sloughing in germinal epithelia (H\&Ex200). 


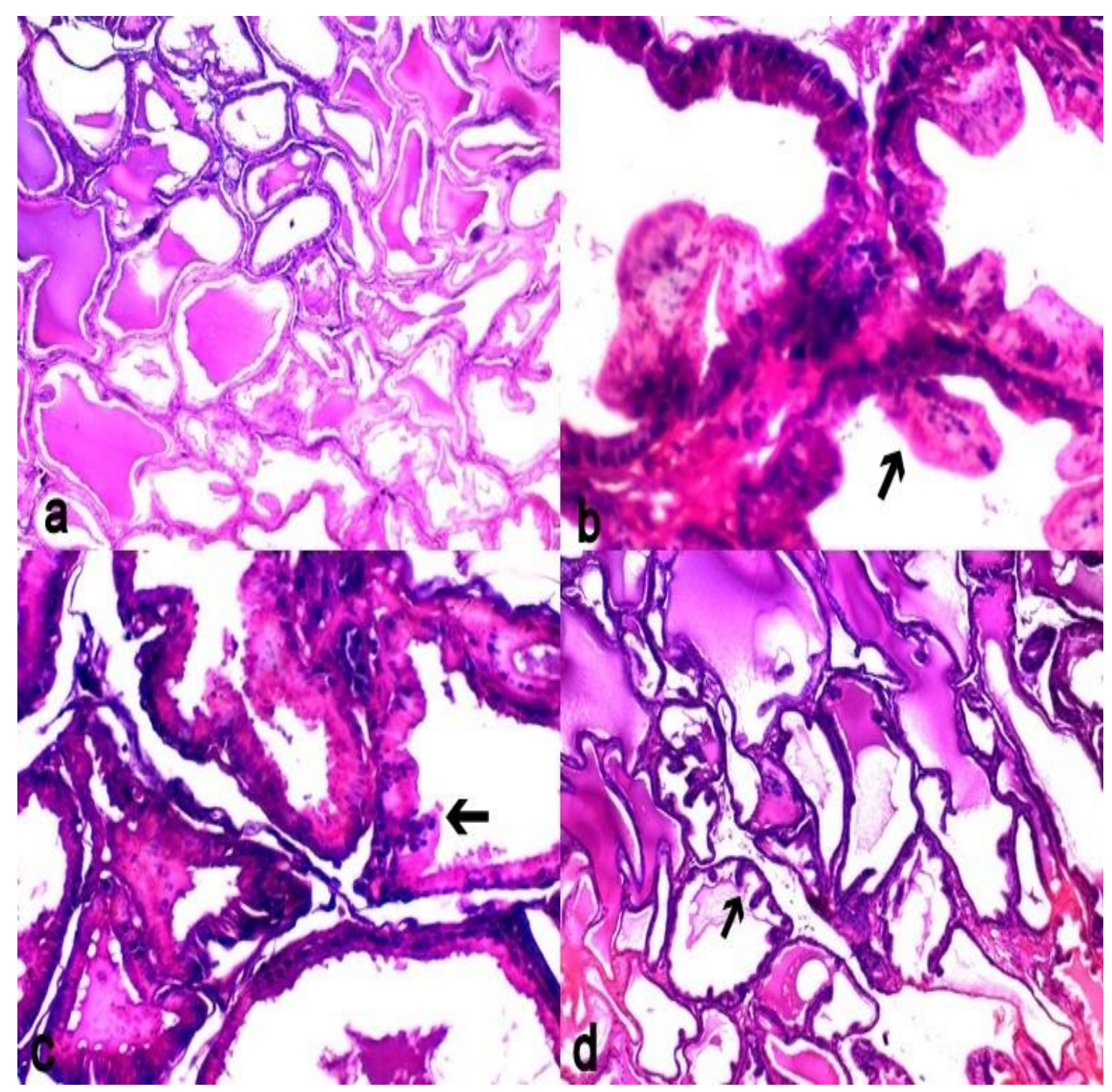

Figure (2):Histopathological features of rat prostste a) Section from control rat showing normal prostatic acini (H\&E x200). b,c)Section from group III( Bisphenol A treated group) showing sever hyperplasia in most of acini in addition to the presence of papillary projections in some of them (arrow) (H\&E x400). d) Section from Group IV(Bisphenol A and vitamin E treated group) showing mild hyperplasia of lining epithelia and few papillary projections toward alveolar lumen (H\&E x200). 


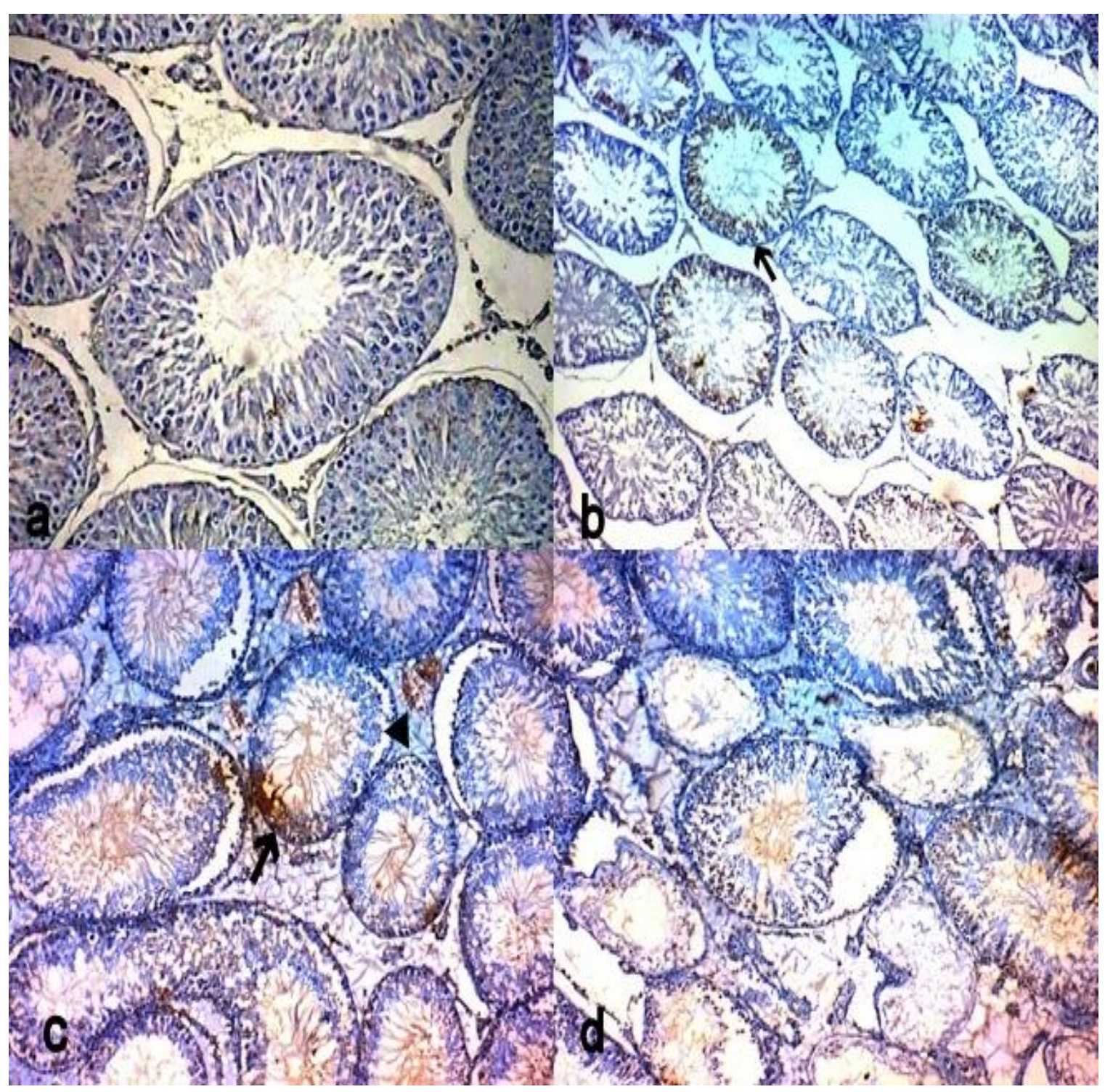

Figure (3): Immunohistochemical staining of caspase-3 in testis a)Section from control rat showing negative expression (Immunoperoxidase $\mathrm{x} 400$ ). b,c) Section from group III (Bisphenol A treated group) showing moderate to strong expression mainly in primary spermatocytes (arrow) and leiydge cells(arrow head) (Immunoperoxidase x200) d) Section from Group IV(Bisphenol A and vitamin E treated group) showing moderate expression in some cells (Immunoperoxidase x200). 


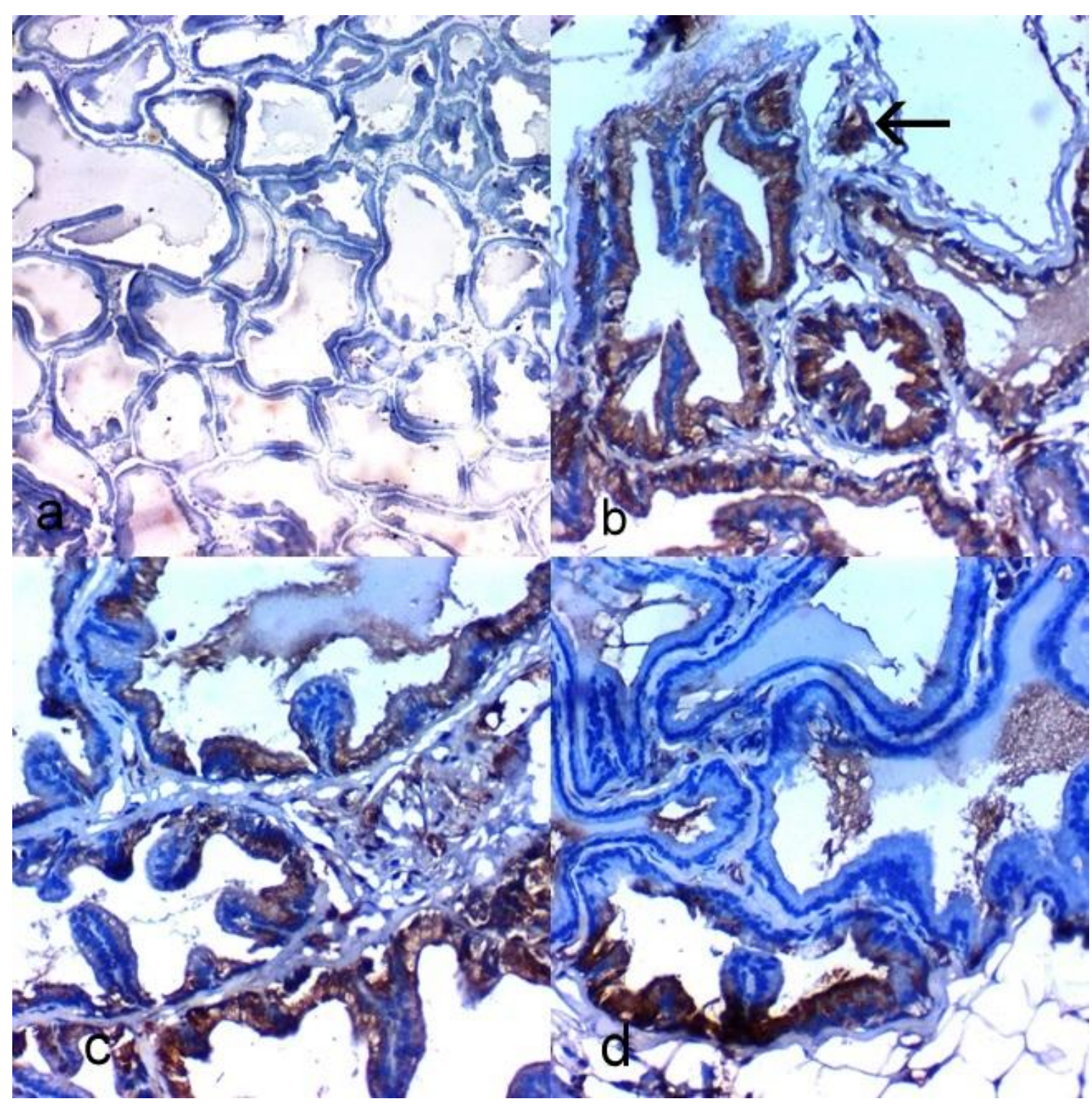

Figure (4): Immunohistochemical staining of caspase-3 in prostate a)Section from control rat showing negative expression (Immunoperoxidase x200). b,c) Section from group III (Bisphenol A treated group) showing moderate to strong expression in most of the cells lining the acini also in sloughed cells in the lumen(arrow) (Immunoperoxidase x400) d) Section from Group IV(Bisphenol A and vitamin $E$ treated group) showing positive expression in some cells lining the acini

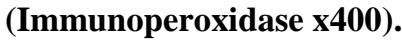

\section{Discussion}

Bisphenol A is harmful to human and animals. It is present in the environment and commonly used in daily life. It affects normal functions of the endocrine and reproductive systems also by simulating or inhibiting the action of endogenous hormone, or modifying the synthesis of hormones (Gurmeet et al., 2014).

Bisphenol A administration to male rats affects androgen receptors, testosterone levels, testis and prostate and also sexual behavior which is considered different parts of reproductive system (ElBassouny and Hindawy, 2013).

With regard to the current study results, it could be established that the recorded mean values of serum testosterone by the end of the 8 weeks of BPA administration were significantly lower than those of the control group $(\mathbf{P}<\mathbf{0 . 0 0 1})$.
These results concede with the results of Gurmeet et al. (2014), Hassan, et al. (2013), Xi et al. (2011) and Nakamura et al. (2010) who noticed significant decline in testosterone level following BPA treatment. The decreased serum testosterone level could be primarily postulated to the diminished expression of the steroidogeneic enzymes and cholesterol carrier protein (steroidogenic acute regulatory protein"StAR") involving the testosterone production as stated by Xi et al. (2011) and Nakamura et al. (2010).

In accordance with these results Akingbemi and co-researchers (2004) also reported lower levels of free plasma testosterone and 17 $\beta$-oestradiol in BPA treated animals. They concluded that testosterone production was reduced due to a direct action of BPA on Leydig cells. This speculation was based on their 
finding that BPA suppressed aromatase gene expressions which lead to reduced 17 $\beta$-oestradiol biosynthesis. Aromatase is an enzyme necessary for aromatization of testosterone to $17 \beta$-oestradiol (Gurmeet et al., 2014). Furthermore, BPA is reported to have an antiandrogenic effect blocking the action of dihydrotestosterone (Lee and Rhee, 2007).

Also, Nakamura et al., (2010) study reported that BPA caused a reduction in the number of Leydig cells as well as the testosterone levels following 6 weeks of subcutaneous administration. The research findings indicated that BPA exposure is not only affecting the development and function of the reproductive organs at puberty but also throughout adulthood (Gurmeet et al., 2014).

The study of Akingbemi et al., (2004) stated that the exposure to BPA has opposing action on testicular function through reducing serum $\mathrm{LH}$ and testosterone levels. As well as measurement of testosterone level after incubation of Leydig cells with BPA, showed dose dependent suppression of Leydig cell androgen synthesis, which was related to inhibition of steroidogenic enzyme activity because there was a decrease in mRNA levels of the P45017_ enzyme. It was found that BPA decresae testosterone yield via reduced LH secretion and interferes with LH sensory receptor -ligand binding resulting in uncoupling of $\mathrm{LH}$ from the LH receptor.

All the findings act together to support that BPA affect the function of testis in term of leydig and sertoli cell function showing embarrassment of testosterone secretion "primary gonadal failure" (Tohei et al.,2001).

On the other hand, reduction of serum testosterone level disagree with results obtained by Kato et al., (2006), kawai et al., (2003).They found that there was non-significant change in testosterone level following BPA exposure when compared with control, Whereas Ramos et al., (2003) found that prenatal BPA exposure (25 and $250 \mu \mathrm{g} / \mathrm{kg} \quad$ b.wt) resulted in significant rise in serum testosterone level at 15thpostnatal day when compared with control. This variation may be due to differences in animal species, dose of BPA and time of exposure.

The results of the present study showed that BPA administration induced several histopathological alterations in the testes and prostate as compared to control groups. The testes shows disorganization, marked sloughing of the germinal epithelium and damage of some seminiferous tubules wall .Also, there is accumulation of pinkish edematous fluid between them .There are few number of spermatids inside the lumen of seminiferous tubules, some of the tubules show no mature spermatozoa in their lumen. The prostate showed marked degree of hyperplasia in most of acini, the hyperplasia obstructed the lumen of some prostatic alveoli .Other alveoli showed the presence of papillary projections in their lumen.

These results are conceded with Gurmeet et al. (2014) who stated that the testes of the animals treated with BPA clearly showed loosening of the intercellular bridges between germ cells as well as between germ cells and Sertoli cells. This was supported by the presence of immature germ cells in the lumen of the seminiferous tubules even with the lowest dose of BPA. Majority of animals in the treated groups did not have mature sperms in their seminiferous tubular lumen, where the seminiferous tubular lumens were filled with cellular debris and immature germ cells.

These results are supported with (Helal et al., 2013) who showed that exposure to BPA in multiple doses and periods, showed different pathological variations in the testis in the form of thick capsules with dilated blood vessels, several seminiferous tubules displayed hypocellularly in the spermatogenic cells. Interstitial space filled with exudate and numbers of Leyding cells were diminished.

These testicular pathological changes may be due to xenoestrogenic properties of BPA which inhibit growth of testicular glands. Where BPA attacks selectively the male reproductive organs and directly affects testicular function as reported by Tohi et al (2001).

Our findings were similar to that obtained by Hussein (2015) where the histopathological examination revealed moderate to severe papillary hyperplasia in the lining epithelia with focal thickening in prostate gland of BPA treated rats. Also, Hassan, et al (2013) demonstrated papillary hyperplasia in the lining epithelia with decrease prostatic secretion in prostate gland of rat pre and postnatal exposed to BPA.

Also, these findings were similar to that obtained by Ramos et al (2013) and Mourad and Khadrawy (2012). The hyperplasia of prostatic acini resulting from increasing the proliferation of basal epithelial cells as declared by Timms et al (2005).

Accordingly, testis and prostate show severe changes with high doses exposure to BPA. These effects are due to the oxidative stress encouraged by BPA which will produce extreme effects after a long term of exposure. Additionally, the study results propose that in people with high use of plastics where there is an excessive chance of contact to BPA, the males may suffer from sexual disturbances due to the oxidative stress effect on the testis (Mourad and Khadrawy, 2012).

In the current work, immunohistochemical examination of the testes and prostate specimens of the rats of BPA group by the end of 8 weeks moderate to heavily labeled active caspase-3-positive cells were seen. In the testes, the active caspase-3immunostaining mainly was observed in Leydig cells and primary spermatocytes, while in prostate it involved cells lining the alveoli.

The above-mentioned results coincided with Li et al., (2009) study, where the relative expression levels ofcaspase-3 were increased in groups treated with different doses of BPA compared with control group. Also expression of active caspase-3 was significantly increased with the rising of BPA dose that reveal a dose dependant apoptosis of both Leydig and germ cells encouraged by BPA.

According to $\mathrm{Li}$ et al., (2009) Leydig and germ cells show apoptosis as a result of exposure to BPA which accompanied by upregulation of caspase3appearance in the testicular tissue. It was found that 
the death of receptors facilitated by Fas which is very important in high-dose BPA-induced apoptosis of cells. The Fas system may be generated through cellular changes in oxidative stress. For our knowledge, this is the first study that assesses the immunohistochemical expression of caspase-3 in rat prostate trated with BPA.

The predominant cause For Leydig cell apoptosis is the interaction between Fas Ligand and Fas, while for germ cell apoptosis, it is more complex process. In contrast, The Bcl-2 family was involved in apoptosis of germ cells via development and of granulosa cells after BPA exposure we conclude that BPA may interrupt spermatogenesis by impacting different testicular cell and by stimulating the Fassignaling pathway (Koji and Hishikawa, 2003).

In the present study, the recorded mean values of serum testosterone by the end of the 8 weeks in BPA and vit $\mathrm{E}$ treated group were slightly improved than in BPA treated group but still show lower results than those of the control group.

Furthermore, Co-administration of Vit E induced partial improvement in histopathological structure in testicular and prostate specimens of the rats. The testes showed irregular placement of germinal epithelium on the basement membrane and disruption. The number of spermatogonia is mildly reduced with some degree of germinal epithelia sloughing.

The prostate demonstrated degeneration of epithelial cell and some epithelia shows sloughing, slight hyperplasia and few papillary projections toward alveolar lumen. Moreover, immunohistochemical examination of caspase-3 showed moderate staining in some cells of the primary spermatocytes and the interstitial leydig cells and in the cells lining the alveoli of prostate.

The protective effect of Vit E on testicular and prostate damage and dysfunction were demonstrated in studies of Srivastava and Gupta (2016) and Fang et al (2013). They showed that supplementation of vitamin E during BPA exposure may have certain protective effect on reproductive inhibition caused by BPA exposure.

Different studies have described the incidence of oxidative stress after exposure to BPA in both rats and mice, which can disrupt reproductive functions (Chitra et al., 2003). Vitamin E ( $\alpha$-tocopherol) is an antioxidant with a strong lipophilic character, can be found in great amounts in Sertoli cells and pachytene spermatocytes but to a slighter level in round spermatids (Yoganathan et al., 1989) another role of vitamin $\mathrm{E}$ is to diminish lipid peroxidation in testicular microsomes and mitochondria and is totally vital for the preservation of mammalian spermatogenic process (Gavazza and Catala, 2006).

\section{Conclusions}

From the results of the current study it has been determined that the xenoestrogen BPA harmfully upset male reproductive system through its action on gonadal steroidogenesis, and afterwards the irregular liberation of testesteron hormone. Supplementation of Vit E during BPA exposure may have protective effects against testicular and prostate dysfunction.

\section{Recommendations}

As human are greatly exposed to BPA and it can accumulate in tissues, there is worry about human reproductive functions particularly for occupational workers exposed usually to greater levels of BPA. Thus, the use of BPA in multiple industries must be restricted and the inaccurate usage of plastic containers should be evaded to decrease the health hazards. Administration of vitamin E may protect against the adverse effects of BPA on reproductive function.

\section{References}

Ahmed W, Moselhy W and Nabil T (2015): Bisphenol A Toxicity in Adult Male Rats: Hematological, Biochemical and Histopathological Approach. Global Veterinaria. 14 (2): 228-238.

Akingbemi B, Sottas C, Koulova A et al., (2004):Inhibition of testicular steroidogenesis by the xenoestrogenbisphenola is associated with reduced pituitary luteinizing hormone secretion and decreased steroidogenic enzyme gene expression in rat Leydig cells. Endocrinology. 145(2):592-603.

Anjum S, Rahman S, Kaur M et al., (2011):Melatonin ameliorates bisphenol A-induced biochemical toxicity in testicular mitochondria of mouse. Food ChemToxicol. 49:2849-2854.

Bancroft and Stevens (1997): Theory and practice of histological techniques. The journal of pathology.183(2): 243-244.

Bosch R, Quiroga B, Moreno C et al., (2016): Bisphenol A: An environmental factor implicated in renal vascular damage. Nefrología. 36 (1):5-9.

Bosnjaka I, Borrab M, Iamunnoc F et al., (2014): Effect of bisphenol A on P-glycoprotein-mediated efflux and ultrastructure of the sea urchin embryo. Aquatic Toxicology. 156: 21-29.

Chapin R, Adams J, Boekelheide K et al. (2008): NTP-CERHR expert panel report on the reproductive and developmental toxicity of bisphenol A. Birth Defects Res B Dev Reprod Toxicol.;83:157-395.

Chitra K, Latchoumycandane C and Mathur P (2003): Induction of oxidative stress by bisphenol $\mathrm{A}$ in the epididymal sperm of rats. Toxicology. 14(1): 119-127.

El-Bassouny D and Hindawy M (2013): The adverse effects of bisphenol ' $A$ ' on some reproductive organs of the male albino rat: a light and electron microscopic study. The Egyptian Journal of Histology 36:564-578.

Elobeid M and Hassan Z (2015): Bisphenol A induced oxidative stress and apoptosis in kidney of male rats. Journal of environmental biology. 39:685-688.

Fang Y, Zhou Y, Zhong Y et al., (2013): Effect of vitamin $E$ on reproductive functions and antioxidant activity of adolescent male mice exposed to bisphenol A. Wei Sheng Yan Jiu. 42(1):18-22.

Gavazza M and Catala A. (2006): The effect of alpha-tocopherolonlipid peroxidation of 
microsomes and mitochondria from rattestis. Prostaglandins Leukot Essent Fatty Acids. 74 (2006): 247-254.

Griffen J and Wilson J (1992): Disorders of the testis and the male reproductive tract. In: Williams Textbook of Endocrinology. (8th ed.), Wilson JD, Foster DW (eds.). Philadelphia: WB Saunders Co. 799-852.

Gurmeet K, Rosnah I, Normadiah M et al., (2014): Detrimental effects of bisphenolA on development and functions of the male reproductive system in experimental rats. Excli journal. 13:151-160.

Hassan A, Ismail A and Khudir A (2013):Effects of Pre-and Postnatal Exposure to Bisphenol- A on the Reproductive Efficacy in Male Albino Rats. Journal of Kerbala University. 11(3): 158-172.

Heindela J, Newboldb R, Bucherb J et al., (2015): NIEHS/FDA CLARITY-BPA research program update. Reproductive Toxicology. 58: 33-44.

Helal E, Badawi M, Soliman M et al., (2013): Physiological and Histopathological studies on Bisphenol-A compound as xenoestrogen in male albino rats. The Egyptian Journal of Hospital Medicine. 50: 127 - 136.

Ho C and Habib F (2011): Estrogen and androgen signaling in the pathogenesis of BPH. Nat Rev Urol. 8(1): 29-41.

Hussein A (2015): Histopathological study of lung, kidney, spleen and prostate in adult male rats treated with bisphenol a. Bas.J.Vet.Res.14( 2): 74- 86.

Kato Y, Furuhashi T, Tanaka M et al., (2006): Effects of bisphenol A given neonatally on reproductive function of male rats. Reproductive Toxicology, 22: 20-29.

Kawai K, Nozaki T, Nishikata H et al., (2003): Aggressive betaviour and serum testosterone concentration during the maturation process of male mice. The effects of fetal exposure to bisphenol A. Environmental Health Perspectives, 111(2).175-178.

Koji T and Hishikawa Y (2003): Germ cell apoptosis and its molecular trigger in mouse testes. Arch. Histol. Cytol. 66(1): 1-16.

Lee I and Rhee S (2007): Inhibitory Effect of Bisphenol A on Gap Junctional Intercellular Communication in an Epithelial Cell line of Rat Mammary Tissue. Arch Pharm Res. 30(3): 337-343.

Li Y, Song T, Cai Y et al., (2009): Bisphenol A Exposure Induces Apoptosis and Upregulation of Fas/FasLand Caspase-3 Expression in the Testes of Mice. Toxicological sciences. 108(2): 427-436.

Mourad I And Khadrawy Y (2012):The sensitivity of liver, kidney and testis of rats to oxidative stress induced by different doses of Bisphenol
A. International journal of life science and pharma research. 2(2): 2250-0480.

Nakamura D, Xanagika Y, Duan Z et al., (2010):Bisphenol A may cause testosterone reduction by adversely affecting both testis and pituitary systems similar to estradiol. Toxicology Letters. 194: 16-25.

Nemzek J, Bolgos G, Williams, B et al (2001): Differences in normal values for murine white blood cell counts and other hematological parameters based on sampling site. Inflammation Research. 50: 523-527.

Ogutcu A, Uzunhisarcikli M Kalender S et al (2006): The effects of organophosphate insecticide diazinon on malondialdehyde levels and myocardial cells in rat heart tissue and protective role of vitamin E. Pestic. Biochem. Physiol. 86:93-98.

Papadopoulosa G, Vlachodimitropoulosa D, Kyroudi A (2013): Terazosin Treatment Induces Caspase-3 Expression in the Rat Ventral ProstateJ Clin Med Res .5(2):127-131

Pekiner B (2003): Vitamin e as an antioxidant. Ankara Ecz.Fak.Derg. J. Fac. Pharm. 32 (4): 243-267.

Preethi S, Sandhya K, Lebonah D et al., (2014): Toxicity of bisphenola on humans: a review. International Letters of Natural Sciences. 27: 32-46.

Ramos J, Vurayoud J, Kass L et al., (2003): BisphenolAinduces both transient and permanent histofunctional alteration of the hypothalamicpituitary - gonadal axis in prenatally exposed male rats. Endocrinology. 144 (7): 3206-15.

Sakuma S, Nakanishi M, Morinaga K et al., (2010): Bisphenol A 3,4-quinone induces the conversion of xanthine dehydrogenase into oxidase in vitro. Food ChemToxicol. 48: 2217-2222.

Srivastava S and Gupta P (2016): Genotoxic and Infertility Effects of Bisphenol A on Wistar Albino rats. Int. J. Pharm. Sci. Rev. Res. 41(1):126-131.

Timms B, Howdeshell K, Barton L et al., (2005): Estrogenic chemicals in plastic and oral contraceptives disrupt development of the fetal mouse prostate and urethra. Proc. Natl. Acad. Sci. 102:7014-7019.

Tohei A, Suda S, Taya K et al., (2001): Bisphenol-A inhibits testicular functions and increased luteinizing hormone secretion in adult male rats. Exp. Brol. Med., 226: 216-221.

Xi W, Lee C, Yeung W et al., (2011): Effect of perinatal and postnatal bisphenol A exposure to the regulatory circuits at the hypothalamus-pituitary-gonadal axis of CD1 mice. Reproductive Toxicology. 31: 409417.

Yoganathan T, Eskild W and Hansson V. (1989): Investigation of detoxification capacity of rat testicular germ cells and Sertolicells. Free RadicBiol Med .7: 355-359. 


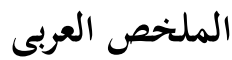

\section{دراسة الأثار السمية المحتملة للبيسفينول أ و الدور الوقائي لفيتامين (ه) على الخصيتين والبروستاتا في ذكور الجرذان البيضاء البالغه}

\section{بثينه حسن فؤادعمران و ايمان عبد الله احمد عبدالله' و مي محمد عبد الوهاب؟}

المقدمة:يـدخل البيسفينول أ في بحموعه واسعه من الصناعات وعادةمايتم الكشف عنه في البيئة ،والتعرض له يمثل ضررا على الجهاز

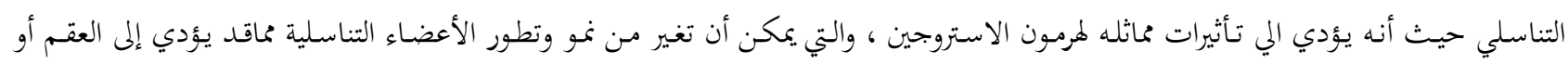
السرطان.

الهـفف:دراسة الأثار السمية المتملة للبيسفينول أ على الخصيتين و البروستاتا في ذكور الجحرذان البيضـاء البالغه , وتقييم الدور الوقائي لفيتامين هـ. المواد والطرق المستخدمة:أجريت هذه الدراسه على عدد •.بمن ذكور الجرذان البيضاء البالغة مقسمة الى عبحموعات كالآتي: البمموعة

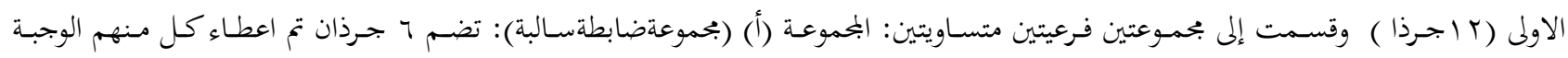

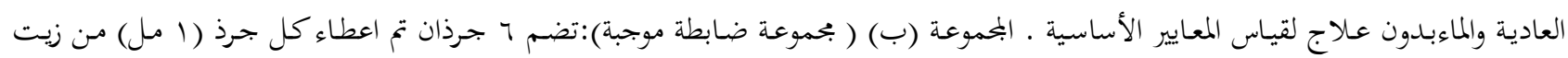

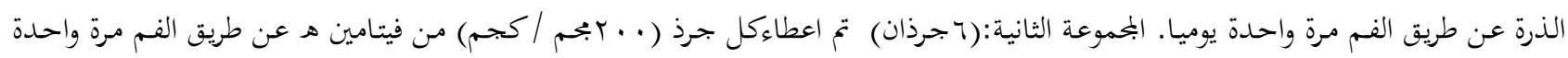

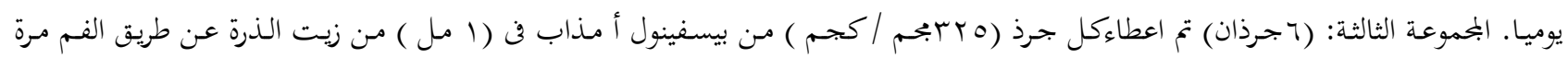

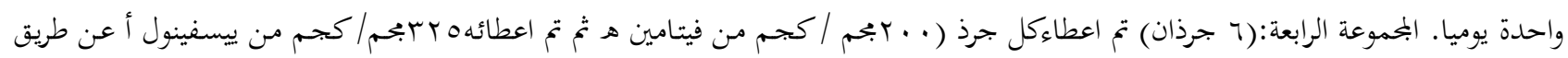

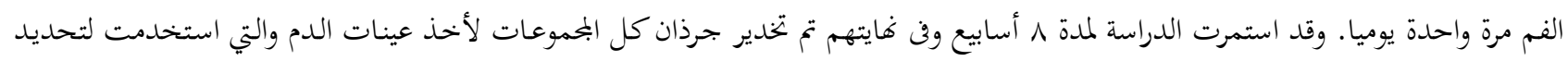

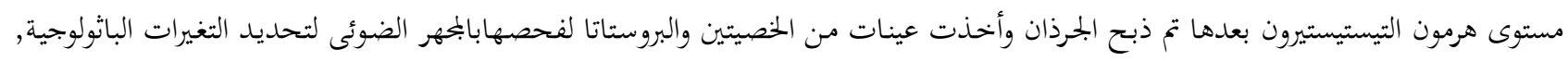

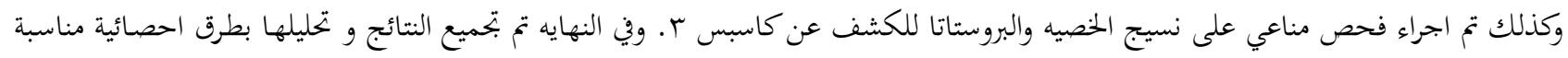
و بحميعها في جداول ومناقشتها.

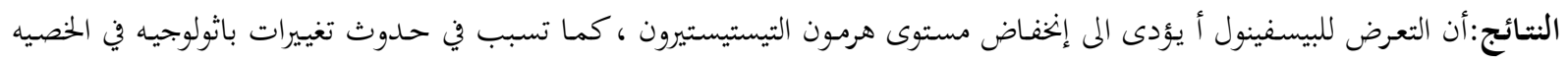

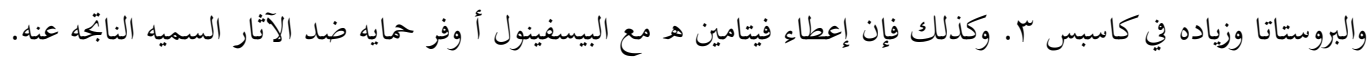

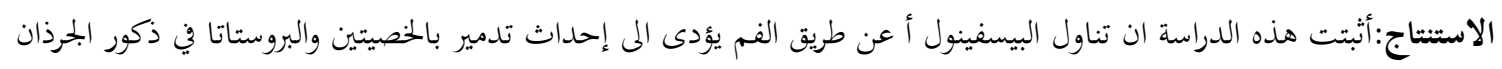

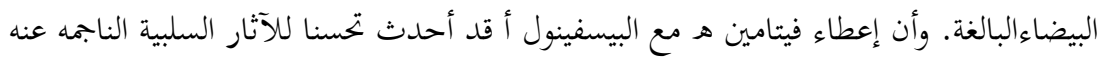

